\title{
Mr Skemp's preposterous provision: the drafting of the Patents Act 1977 and harmonization in the 1970s
}

\author{
Phillip Johnson \\ Professor of Commercial Law, Cardiff University
}

The Patents Act 1977 created a new law of patents based on the European Patent Convention (1973). However, the wording of the Act did not 'copy out' the text of the Convention, but was drafted in traditional statutory language to give it effect. Nevertheless, to facilitate harmonization, the Act included a unique provision in British law: section 130(7). Both the drafter's approach and this 'preposterous' provision have been lamented by the patent judiciary for nearly four decades. But is this criticism fair?

Keywords: Patents Act 1977, European Patent Convention, legislative drafting, implementing treaties, harmonization

\section{INTRODUCTION}

It is the lot of Parliamentary drafters to be criticized by judges. ${ }^{1}$ Nevertheless Terence Skemp, ${ }^{2}$ Second Parliamentary Counsel and the lead ${ }^{3}$ draftsman of the Patents Act 1977, has received more criticism than most - yet his drafting has worked for nearly 40 years. The essential criticism, that he did not 'copy out' the wording of the Convention, is encapsulated in the comments of Jacob $\mathrm{J}$ in Beloit Technologies Inc. $v$ Valmet Paper Machinery (No 2) Inc.: ${ }^{4}$

1. For some examples, see Renton Committee on the Preparation of Legislation (1975) (Cmdn 6053), Appendix B. Although outside the scope of this discussion, the Patents Act 1977 also received criticism for the clarity of its drafting: EWE Micklethwait, 'The Drafting of the Patents Bill' (1977) 6 CIPA Journal 194; and Letter from EWE Micklethwait (1977) 6 CIPA J 404.

2. Terence RF Skemp CB, QC was born in 1915, called to the bar by Gray's Inn in 1938, joined the Parliamentary Counsel Office in 1946, became a full Parliamentary Counsel in 1964, and became Second Parliamentary Counsel (the second most senior drafter in the Office) in 1973. After his retirement in 1980 he became Counsel to the Speaker. He died in 1996. See Who Was Who, 1920-2014, online edition (A \& C Black/Oxford University Press, April 2014). 3. Until 2010, each Bill was worked on by a Parliamentary Counsel (or Deputy) with an assistant or devil: see Daniel Greenberg, Laying Down the Law (Sweet and Maxwell 2011) at 21-2. The Devils on the Patents Bill were EG Bowman (later Sir Geoffrey Bowman KCB, QC, First Parliamentary Counsel, 2002-2006) and E Sutherland (later, Euan Sutherland CB, Parliamentary Counsel, 1989-2003): see Who Was Who, 1920-2014, online edition (A \& C Black/ Oxford University Press, April 2014).

4. [1995] RPC 705 at 737; also see Lenzing AG European Patent [1997] RPC 245, 259, Jacob J. 
I would say this: it is a great pity that the 1977 Act did not follow the actual language of the EPC where it was seeking to implement it. Speaking generally it helps no-one for the Parliamentary draftsman to re-write matter in a treaty or convention (or EU directive for that matter) which is to be implemented in the United Kingdom. If the language of the basic document is obscure or less than complete it makes things worse if the Parliamentary draftsman tries to 'clarify' it in some other words. Where he does he simply causes extra complications (and therefore legal uncertainty and costs). The point at which obscurities should be avoided is in the underlying international document. If they are unfortunately there, it is too late for our Parliamentary draftsman to help and the problem must be left for industry to pay for in the courts. The particular question here is a typical example of what could be avoided by simply adopting the language of the underlying document as it stands. I hope that those concerned in the future with implementation of treaties, conventions or EU directives (at least in the intellectual property field) will take this into account.

He expressed similar thoughts a decade later in Rhone-Poulec-Rorer International $v$ Yeda Holdings: ${ }^{5}$

Our Parliamentary draftsmen have a curious, and entirely less than helpful, practice, when implementing an international treaty as part of UK law of re-writing specific provisions which are meant to be implemented directly. I can understand why, when the Treaty concerned gives a measure of discretion as to how it is to be implemented, there is a need for our Parliamentary draftsman to work out for themselves how the implementation is to be effected, but I cannot see, and never have seen, any point in trying to re-write a specific provision which has to be implemented as is. I cannot understand how there can even be a sensible debate about the merits of re-write versus copy-out in such a case.

These short passages, which seem so reasonable, need to be evaluated in the context of the law as it was in the 1970s. Indeed, Mr Skemp, as other Parliamentary drafters before and after, cannot defend his work or explain his reasoning. By examining the law as it stood in the mid 1970s and looking at the Bill papers for the Patents Act $1977,{ }^{6}$ this discussion will consider the merits of 'Mr Skemp's Act'.

\section{JUDGE PROOF LAW}

When the Patents Bill was being drafted in 1976 and $1977,{ }^{7}$ the main aim of Parliamentary Counsel was to make the law 'judge proof', that is, drafted in such a way that a judge could not interpret the law in a way which was contrary to that which the draftsman intended. The reasons were aptly put by Sir Harold Kent in his memoirs: ${ }^{8}$

5. [2006] EWCA Civ 1094, [2007] RPC 9 at [22]; similar view were also expressed in Aerotel v Telco Holdings [2006] EWCA Civ 1371, [2007] RPC 7 at [6]; Menashe Business Mercantile Ltd $v$ William Hill Organisation Ltd [2002] EWHC 397 (Pat); [2002] RPC 47 and Markem Corp. v Zipher Ltd [2005] EWCA Civ 267, [2005] RPC 31 at [94]. He made similar comments on other areas of legislation as well: Customs and Excise Commissioners v Century Life Plc [2001] STC 38 (VAT); British Sugar Plc v James Robertson \& Sons Ltd [1996] RPC 281 at 291; and Philips Electronics NV v Remington Consumer Products Ltd [1998] RPC 283 at 290 (both trade mark cases).

6. Parliamentary Counsel's Papers for the Patents Bill 1977 (National Archive, held under Special Arrangement by the Parliamentary Counsel's Office) ('Patents Bill Papers').

7. This is still the aim, but other objectives now appear to be equal to this one.

8. Sir Harold Kent, In on the Act: Memoirs of a Lawmaker (Macmillan 1979) at 103. 
For ten years I acted for the Crown as Treasury Solicitor, sometimes in cases where private citizens were trying to benefit from gaps and obscurities in Acts of Parliament. In such cases judges did not exactly fall over themselves to fill the gaps and clarify the obscurities in such a way as to give effect to what we thought was the intention of the Act. They construed it literally and strictly and were sometimes rather pleased to find that the subject had outwitted the Government and Parliament. Indeed, this is one of the reasons why Acts of Parliament try to cover all possible eventualities.

This memoir was published two years after the enactment of the Patents Act 1977 by someone who had not only been Parliamentary Counsel in an earlier era, ${ }^{9}$ but could speak with authority on the problems that came from imprecise drafting. ${ }^{10}$ As the following extract from the Patents Bill Papers demonstrates, Mr Skemp whilst trying to follow the European Patent Convention (EPC) had similar concerns to Sir Harold: ${ }^{11}$

I agreed perhaps too readily to follow the EPC on this subject ... One of the difficulties of language is that our statutes are aimed at a different legislative audience from Continental legislation or, indeed, international conventions. We aim for precision and, at the end of the day, we aim to make our Bills 'judge-proof' ... I think any judge faced with the kind of drafting typified by the enclosed clauses would twig that we are following the convention as closely as possible and would act accordingly. But I have been long enough in this game to know that you can never be sure with judges. However, I am personally prepared to take the risk.

The basis of the cynical view of judges held by both Sir Harold and Mr Skemp - at least in relation to the implementation of treaties - becomes more apparent when the applicable canons of construction are considered.

\section{THE IMPLEMENTATION OF TREATIES IN THE UNITED KINGDOM}

The United Kingdom adopts the classic dualist approach to treaties. The Crown has the power to sign a treaty and, until recently, ${ }^{12}$ it could even bind the United Kingdom without consulting Parliament. ${ }^{13}$ But such a signature (or ratification) has effect only in international law, it has no effect in domestic law. Legislation is usually necessary to give to a Convention effect in domestic law and such legislation usually takes one of two different forms. ${ }^{14}$ The first is Scheduling a Convention to the legislation and the text of the Convention itself essentially becomes a statute. The second form

9. Sir Harold Kent GCB, QC had been Parliamentary Counsel 1940-1953 and then Treasury Solicitor 1953-1963.

10. He also mentions something he calls Rowlatt's law - 'The intelligibility of a Bill is in inverse proportion to it being right' - in In on the Act: Memoirs of a Lawmaker (Macmillan 1979) at 97, 102-103. This rule was apparently stated by John Rowlatt (later Sir John Rowlatt, First Parliamentary Counsel, 1953-1956).

11. Letter from Skemp to John Evans (Solicitor, Department of Trade): Patents Bill, 29 July 1976 (Patents Bill Papers).

12. It is now the case that the treaty must be laid before Parliament and may only be ratified if there is no resolution of Parliament against ratification: see Constitutional Reform and Governance Act 2010, Part 2.

13. This was the case under the old Ponsonby rule: in relation to scrutiny, see Joanne Harrington 'Scrutiny and Approval: The Role of Westminster-Style Parliaments in Treaty Making' (2006) 55 ICLQ 120 (the Ponsonby rule and UK scrutiny is explained at 126-31).

14. There are more options than this when the full range of international instruments is considered: see Anthony Aust, Modern Treaty Law and Practice (3rd edn, Cambridge 2013) at 168-71. 
is drafting national law in such a way that it is (believed to be) compliant with the Convention.

A well-known example of the first approach is the implementation of the Rome Convention on the law applicable to contracts ${ }^{15}$ where section 2(1) of the Contracts (Applicable Law) Act 1990 simply states that 'the Conventions shall have the force of law in the United Kingdom'. ${ }^{16}$ This approach has never been used in relation to patent conventions, but was used over a century ago in relation to the original ratification of the Berne Convention for the Protection of Literary and Artistic Works. Thus, an Order in Council ${ }^{17}$ under the International Copyright Acts 1844 to 1886 stated simply that ' $[\mathrm{t}]$ he Convention as set forth in the ... Schedule to this Order shall ... have full effect throughout Her Majesty's dominions' ${ }^{18}$ This made an English translation of the original Berne Convention part of domestic legislation and so the text of the Berne Convention itself ${ }^{19}$ could be treated as an Act of Parliament. ${ }^{20}$ The second approach to implementation, namely drafting the law to be compliant, is the approach that has been adopted in relation to patents legislation. ${ }^{21}$ Typically, therefore, the words of the legislation were not the same as those in the Convention itself - making uniformity of interpretation a difficult thing.

\section{THE ABSENCE OF UNIFORMITY}

At the outset it is important to acknowledge that many treaties, whatever the field of law, are not really a search for uniformity but, as Philip Allott put it, 'a disagreement reduced to writing'. ${ }^{22}$ Thus, when the words in a Convention are first interpreted they are not necessarily the result of what the parties either individually or collectively want, but what both parties can accept. ${ }^{23}$ Treaties are political compromises which are often accepted for their vagueness and ambiguity, as Lord Phillips stated in the Supreme Court in Assange v Sweden: ${ }^{24}$

... the text of much European legislation is arrived at more through a process of political compromise, so that individual words may be chosen less for their legal certainty than for their political acceptability ...

15. 80/934/EEC [1980] OJ L266/1.

16. Albeit subject to some reservations: see ss 2(2); and, in any event, effectively superseded by the Rome I Regulation (EC) No 593/2008.

17. Order in Council dated 28 November 1887 (published in the London Gazette, 2 December 1887, Number 25763, p. 6703).

18. Article 1 of the Order in Council dated 28 November 1887 (there were modifications but they are not relevant to the present discussion).

19. At this time the official language of the Convention was French and so it was not actually the words of the Convention, but a translation of them, that represented British law.

20. Re 'Morocco Bound' Syndicate [1895] 1 Ch 534.

21. It is suggested in Bennion on Statutory Interpretation (6th edn, Butterworths 2013) at 633

and 634 that this is still the best way to implement (except for the purposes of uniformity).

22. Philip Allott, 'The Concept of International Law' (1999) 10 EIJL 31, 43.

23. Ibid.

24. [2012] UKSC 22, [2012] 2 AC 471 at [14]; the comment was based on Daniel Greenberg (ed.), Craies on Legislation (9th edn, Sweet and Maxwell 2008) at [31.1.21]. 
Whether compromise or not, a uniform text is useful to the development of uniform rules under international conventions. But as John Honnold has said, '[e]ven if you get uniform laws you won't get uniform results', ${ }^{25}$ and, as Munday notes,

even when outward uniformity is achieved following the adoption of a single authoritative text, uniform application of the agreed rules is by no means guaranteed, as in practice different countries almost inevitably come to put different interpretations upon the same enacted words. $^{26}$

Thus, what makes the European Patent Convention different from other international treaties is not that the same text is adopted, but the existence of an active central tribunal, the Boards of Appeal, with its own jurisprudence. But what is important for the current discussion is understanding how the courts in the 1970s would (or would not) use an international treaty to assist in statutory interpretation. ${ }^{27}$

\section{THE APPROACH OF THE ENGLISH COURTS TO INTERNATIONAL TREATIES IN THE EARLY 1970S}

The dualist nature of the English approach to treaties meant that at one time the treaty itself could not even be considered by the court when interpreting the implementing Act of Parliament. The classic exposition of this rule was in the opinion of Lord Tomlin in Ellerman Lines $v$ Murray: ${ }^{28}$

Nor do I think that, assuming there is any divergence between the draft convention and the Act, it would be proper to resort to the draft convention for the purpose of giving to the section a meaning other than that which in my judgment is its natural meaning.

Thus, absent ambiguity, the words of the treaty itself were utterly irrelevant. The rule in Ellerman was (at least believed) to provide a general rule that the text or material associated with a treaty could not be used to help interpret an Act of Parliament giving effect to that treaty where the meaning in the Act was clear. Indeed, where the Court of Appeal did refer to an international (copyright) convention in Hogg v Toye, ${ }^{29}$ a

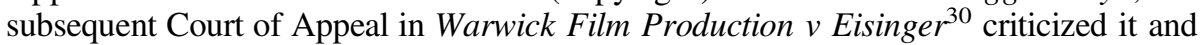
said the decision must be considered to be per incurium. How restrictive this rule was can be seen from extracts from two leading contemporary commentaries on Statutory Interpretation, the first being Maxwell on the Interpretation of Statutes (1969): ${ }^{31}$

25. John Honnold, 'The Sales Convention in Action - Uniform International Words: Uniform Application?' (1988) 8 J \& Comm 207 at 207.

26. R Mundy, 'The Uniform Interpretation of International Conventions' (1978) 27 ICLQ 450 at 450 .

27. For a contemporary discussion of this issue in relation to the Patents Act 1977, see TC Stancliffe, 'EPC, The New Patents Act and the Courts' (1977) 6 CIPA J 254; and Letter from Mr LW Melville, 'EPC, The New Patents Act and the Courts' (1977) 6 CIPA J 406.

28. [1931] AC 126 at 147.

29. [1935] Ch 497 at 520, Maugham LJ.

30. [1969] 1 Ch 508 at 523 (adopting remarks in Halsbury's Laws of England (3rd edn), vol 36 at 411); this case is also mentioned in Report of the Renton Committee on the Preparation of Legislation (Cmnd 6053) at [19.22].

31. P St J Langan (ed.), Maxwell on the Interpretation of Statutes (12th edn, Sweet and Maxwell 1969) at 54. 
International conventions may not be resorted to for the purpose of interpreting legislation which does not contain any ambiguities.

The second is Sir Rupert Cross, who also sets out the rule in its strictest form and then calls for reform in his text Statutory Interpretation (1976): ${ }^{32}$

[The House of Lords in Ellerman] refused to give the words the meaning which they were intended to bear by an international convention mentioned in the long as well as short title, referred to in the preamble and partially set out in the Schedule ... The lesson to be learnt from Ellerman Lines v Murray is that there should be a special rule concerning statutes which are expressed, or even commonly known, to be the implementation of treaties or international conventions.

The tide began to turn in the late 1960s following the judicial activism of Diplock LJ. In Salomon v Commissioners of Customs and Excise, ${ }^{33}$ he stated:

there is a prima facie presumption that Parliament does not intend to act in breach of international law, including therein specific treaty obligations; and if one of the meanings that can be reasonably attributed to the legislation is consonant with the treaty obligations and another or others are not, the meaning which is so consonant is to be preferred. ${ }^{34}$

However, this loosening of the rule only applied when there was an ambiguity in the domestic legislation and so did not reverse the general rule as set out in Ellerman as was made clear by Diplock LJ himself in Post Office v Estuary Radio: ${ }^{35}$

If its meaning is clear, we must give effect to it, even if it is different from that of the Convention, for the Crown may have changed its mind in the period which elapsed between its ratification of the Convention on March 14, 1960, and the promulgation of the Order in Council, and the Crown has a sovereign right, which the court cannot question, to change its policy, even if this involves breaking an international convention to which it is a party and which has come into force so recently as fifteen days before.

But there is a presumption that the Crown did not intend to break an international treaty ..., and if there is any ambiguity in the Order in Council, it should be resolved so as to accord with the provisions of the Convention in so far as that is a plausible meaning of the express words of the order. Furthermore, the fact that the Order in Council uses different words from the Convention does not of itself give rise to any inference that a different meaning was intended.

This increasing flexibility was supported by the Renton Committee, who were considering the drafting of legislation and reported in 1975, and who proposed that the judiciary should be able to consider any international treaty which the legislation was intending to implement. ${ }^{36}$ However, even though the Committee took a bold line on statutory interpretation, it still thought that the 'unrestricted admission' of treaty material would place too great a burden on the court and parties. ${ }^{37}$ Further, they thought that it would not make the legislation more intelligible to the lay public and it

32. R Cross, Statutory Interpretation (Butterworths 1976) at 139-41.

33. [1967] 2 QB 116 at 143.

34. [1967] 2 QB 116 at 145, Diplock LJ.

35. [1968] 2 QB 740 at 757, Diplock LJ; also see Corocraft Ltd v Pan American Airways Inc. [1969] 1 QB 616.

36. Renton Committee on the Preparation of Legislation (1975) (Cmdn 6053) at [19.16].

37. Renton Committee on the Preparation of Legislation (1975) (Cmdn 6053) at [19.23]. 
would lengthen court proceedings; ${ }^{38}$ accordingly, it was for Parliament to declare in an Act of Parliament itself when extrinsic material could be used for interpreting it. ${ }^{39}$ And when legislation is implementing a treaty, Parliament should say so and provide that it is permissible to look at Treaty material. ${ }^{40}$ Only some of the Renton proposals were adopted, which did not include the modest proposals to use international legal instruments for statutory interpretation. ${ }^{41}$

\section{COPY-OUT}

In the mid 1970s, a straightforward copy-out approach of the EPC would not have enabled English courts to refer to the Convention itself at least under the then current canons of construction - even the more liberal ones advocated by Diplock LJ - as ambiguity was still required. Indeed, it must be remembered that the interpretative rule was little different for European (Economic Community) legislation where ambiguity still played a role in liberating judges from strict domestic rules of statutory interpretation. ${ }^{42}$ Accordingly, to look to the Convention for guidance, the patent judges would need to have found (or created) ambiguity in the text of the EPC as copied out in the Patents Act 1977.

Thus, even if copy-out were adopted in the Patents Act 1977, it would not necessarily mean that the interpretation of the EPC would have been the same in the United Kingdom and elsewhere. Even now it is the case that two national courts, even when applying the same international norm, may come to very different conclusions. ${ }^{43}$ Thus, at the time of enactment of the 1977 Act, the new norms in the EPC would probably have been viewed by English courts through local lenses (and to some extent still $\left.\mathrm{are}^{44}\right)$. Consistency of language does not mean consistency of outcome between Member States. Indeed, this is made clear by a 1970s discussion of the Convention on the Contract for the International Carriage of Goods by Road (CMR) where the interpretation of a provision in that convention across contracting states found 20 judgments

38. Renton Committee on the Preparation of Legislation (1975) (Cmdn 6053) at [19.23].

39. In this regard, the Contracts (Applicable Law) Act 1990 is a good example, s 3 allows the Courts to consider the contents of the Giuliano and Lagarde Reports on the Rome Convention on the law applicable to contractual obligations [1980] OJ C 282/1.

40. Renton Committee on the Preparation of Legislation (1975) (Cmdn 6053) at [19.39].

41. See Sir David Renton, 'Failure to Implement the Renton Report' in Francis Bennion (ed.), Renton and the Need for Reform (Statute Law Society 1979) 2.

42. Indirect effect was a creature of the 1980s: see Case No 79/83 Van Colsen [1984] ECR 1891 and C-106/89 Marleasing SA v La Comercial Internacional de Alimentacion SA Marleasing [1990] ECR I-4135. See the House of Lords decision in Duke Appellant v GEC Reliance Ltd [1988] AC 618 where the normal canons of construction were applied to domestic statutes even where they were contrary to Community law (in a case where the law was not intended to implement Community (EU) law).

43. Anthea Roberts, 'Comparative International Law: The Role of National Courts in Creating and Enforcing International Law' (2011) 60 ICLQ 57, uses the example of Ferrini v Germany (2006) 128 ILR 658 and Jones $v$ Saudi Arabia [2006] UKHL 26.

44. See Actavis UK Limited v Novartis AG [2010] EWCA Civ 82, [2010] FSR 18; this was something raised by John CH Ellis, 'Terminological Differences between the Patents Act 1977 and the European and Community Patent Conventions' in Mary Vitoria (ed.), The Patents Act 1977: Queen Mary College Patent Conference Papers (Sweet and Maxwell 1978) 21 at 27. 
with at least a dozen different interpretations. ${ }^{45}$ Thus, in the 1970 s, copy-out alone would not provide uniformity. Against this backdrop, it is appropriate to consider the internal debates over the drafting of the Patents Act 1977 as evidenced from Parliamentary Counsel's Bill papers.

\section{MR SKEMP'S INSTRUCTIONS AND THE PATENTS BILL}

The initial instructions from the Patent Office, through the Department of Trade solicitors, were for the drafting of the Patents Bill to conform to the Conventions, but Mr Skemp's concerns on this were explained soon after he read the instructions: ${ }^{46}$

You have to remember that continental legislative draftsmen have a different aim from draftsmen trained in the British tradition. It may well be that draftsmen of Treaties and Conventions differ from both, but the draftsmen of the EPC have certainly used a different approach from that used in our legislation.

The fact is that we are in a dilemma. I can quite understand the desire of the Patent Office to stick as closely as possible to the EPC, because in that way European developments will (they think and hope) be followed through into our law, but at the end of the day our Bills still have to be judge-proof and our judges are still bound by the comparatively old fashioned British approach to legislation and British rules of construction.

When Philip Bovey, a solicitor on the Bill team at the Department of Trade, responded ${ }^{47}$ he set out two reasons for wanting to have conforming language. The first was the Resolution on the Adjustment of National Patent $\mathrm{Law}^{48}$ (the Adjustment Resolution) and the second was:

European patents designating the UK are to be judged (for validity, extent of protection etc) as if a national patent had been granted to the applicant on the basis of a national application in the same terms. To the extent that our system differs from the European one, problems will therefore arise in dealing with $\mathrm{Ep}(\mathrm{UK}) \mathrm{s}$.

He went on to explain:

The first difficulty is that the EPC creates a functioning organism which will be making decisions and interpreting the Convention producing results on which our courts will have to decide. Even so, this could be solved comparatively easily but for the existence of the CPC [Community Patent Convention]: patents (apart from Community patents) are clearly intended to be subjected to national interpretation.

... It is desired that in the UK the same invention be patentable under all three systems and that the effects of a patent ... be the same.

45. R Wijffels, 'Legal Interpretation of CMR: The Continental Viewpoint' (1976) 11 European Transport Law 208; also see Pierre Lescot, 'L'interprétation judiciaire des règles du droit privé uniforme' [1963] JCP I 1756; and Paul Lagarde, 'Les interpretations divergentes d'une loi uniforme donnent-elles lie à un conflit de lois?' (1964) RCDP 235.

46. Letter from Skemp to Philip Bovey (Solicitor, Department of Trade): Patent Bill: Print 186-1: Letter 1, 19 August 1976 (Patents Bill Papers).

47. Letter from Bovey to Bowman: Patents Bill: Print 186-1: Letter A, 9 September 1976 (Patents Bill Papers).

48. See Community Patent Convention (Cmnd 6553). 
Mr Skemp's instructions were therefore to ensure the 'minimum duality' of standards on substantive law and a rule so that:

the UK courts ... have due regard to European practice and interpretation even where there is no specific Treaty obligation at issue, thus going beyond the established principle in Saloman v Commissioners of Customs and Excise [1967] 2 QB 116 but without subordinating ourselves to the European system.

Mr Skemp responded to his instructions by, amongst other things, proposing a first draft of what was to become section 130(7) of the Patents Act 1977. ${ }^{49}$ Yet it appears he followed the text of the Convention too closely.

\section{THE INITIAL MUSING OF THE PATENTS JUDGES}

On 30 November 1976, after seeing a draft of the Bill, Whitford $\mathrm{J}^{50}$ (endorsed by Graham $\mathrm{J}^{51}$ ) wrote to the Lord Chancellor's Department ${ }^{52}$ expressing the following view:

A parliamentary draftsman can only do his best on the brief he is given. I suspect that [in] section 2, as in section 1 and indeed other sections of the Bill the draftsman was told to get in line with Europe. In the result the inadequacies of the Convention are going to be spelled out again in our domestic law when we should have been trying to give a more positive shape to what was inevitably, as is the case with all Conventions, a somewhat unsatisfactory compromise.

Thus, the patent judges of the day originally took the view that the Patents Bill was too similar to the European Patent Convention and it was appropriate to make it more English (and less of a 'copy-out'). A conclusion diametrically opposed to the view expressed by Jacob J two decades later in Beloit. Furthermore, the patent judges were not being unduly conservative as the 1970s rules on interpreting Acts of Parliament, even where they gave effect to international conventions, were clear. Accordingly, when the Bill was introduced to the House of Lords on 20 December $1976^{53}$ the judges believed the drafting to be too close to the Conventions. Indeed, when Mr Skemp wrote to the Attorney-General (who would put the Bill before Legislative Committee ${ }^{54}$ ) he explained how he was:

forced against my will to use the language of the European Patent Convention and the Community Patent Convention. This has produced some inept drafting ... [where] I was forced to follow ... the European Convention. Indeed, clause 117(4) [section 130(7)] of the Bill invites the courts (in rather a novel manner) to have regard to these Conventions in construing them

49. Letter from Skemp to Evans: Patent Bill, 24 September 1976 (Patents Bill Papers).

50. Judge of the High Court of England and Wales (Chancery Division) (Patents judge) from 1970 to 1988 .

51. Judge of the High Court of England and Wales (Chancery Division) (Patents judge) from 1969 to 1981.

52. The original letter does not appear to exist, but the extract of the letter is included in later correspondence: Letter from Sir Denis Dobson (Permanent Secretary, LCD) to Graham J: Patents Bill, 25 March 1977 (Patents Bill Papers).

53. HL Deb 20 December 1976 vol. 378 col. 1079.

54. The committee which needs to approve all Bills before introduction: see Daniel Greenberg, Laying Down the Law (Sweet and Maxwell 2011) at Chapter 14. 
and comparable provisions of the Bill. I simply mention this in case you should find yourself compelled to defend the unsatisfactory drafting of these provisions in the House. ${ }^{55}$

\section{THE CHARTERED INSTITUTE OF PATENT AGENTS STARTS LOBBYING}

The judges may have thought that Mr Skemp copied out too much of the Conventions; the Chartered Institute of Patent Agents (CIPA), and more particularly John CH Ellis ${ }^{56}$ as Chair of the Home Laws Committee, believed that he did not copy them out enough. ${ }^{57}$ The issue of the Bill's drafting was raised by him at a General Meeting of CIPA on 11 March $1977^{58}$ and again in Council that April. ${ }^{59}$ This concern led him ${ }^{60}$ to write to the patent judges ${ }^{61}$ and the Patent Office to express his concerns about the drafting of the Bill. He believed that the difference in language between the Bill and the Conventions would mean a difference in effect ${ }^{62}$ and so he thought it would mean decisions of the English courts could easily be ignored in other countries. ${ }^{63}$ His letter to the judges set the cat amongst the pigeons.

\section{THE JUDGE'S MEMORANDUM}

During the Second reading debate, ${ }^{64}$ the drafting of the Bill was raised but matters came to a head in March 1977 while the Patents Bill was in the latter stages of Committee in the House of Lords ${ }^{65}$ when Graham J (after reading Mr Ellis's letter) did an about-turn and sent a memorandum to the Lord Chancellor's Department complaining that the Bill was not 'copy-out' enough and stated what should be done:

55. Letter from Skemp to Samuel Silkin, QC MP (The Attorney-General), 7 December 1976 (Patents Bill Papers).

56. He was a Patent Attorney and Solicitor, a member of the Comptroller's Standing Advisory Committee (Patents) and a member of the Banks Committee. He was also awarded a CBE in 1976.

57. For a discussion of the lobbying by CIPA during the passage of the Bill see: Patent Law Reform (1977) 6 CIPA J 534 (particularly at 541). For his views after the process was over, see John CH Ellis, 'Terminological Differences between the Patents Act 1977 and the European and Community Patent Conventions' in Mary Vitoria (ed.), The Patents Act 1977: Queen Mary College Patent Conference Papers (Sweet and Maxwell 1978) 21.

58. See General Meeting (1977) 6 CIPA J 332.

59. See Council News (1977) 6 CIPA J 343 at 343.

60. He saw the Bill in November, but did not make the point then: Letter (No 4189) from Skemp to Michael Collon (Policy, Lord Chancellors Department), 21 March 1977 (Patents Bill Papers).

61. The memorandum was given to the LCO on 16 March 1977.

62. The letter is lost, but the points of concern over the drafting remain on the files: JAC Ellis, 'Some points of difference between Patents Bill, EPC \& CPC' dated 25 March 1977 (Patents Bill Papers).

63. Mr Justice Graham Memorandum, p. 1 (Patents Bill Papers).

64. HL Deb, 24 January 1977, Vol. 379, cols 246 and 247 (Lord Lyell), cols 303 and 305 (Lord Alexander) and cols 313 and 314 (the Lord Chancellor).

65. The House of Lords Committee considered from clause 90 on 22 March 1977: HL Deb 22 March 1977 vol. 381, cols 435-79. 
The remedy is simple and is, of course, wherever possible to use the words of the official text. If this is done, it will then be for our Courts to interpret these words in accordance with the proper principles of interpretation in such a case.

Mr Justice Graham then goes on to state these principles had changed following the Court of Appeal's decision in James Buchanan v Babco ${ }^{66}$ and he cited the following passage from the judgment of Lord Denning:

When they come upon a situation which is to their minds within the spirit - but not the letter of the legislation, they solve the problem by looking at the design and purpose of the legislature - at the effect which it was sought to achieve. They then interpret the legislation so as to produce the desired effect. This means that they fill in gaps, quite unashamedly, without hesitation. They ask simply: what is the sensible way of dealing with this situation so as to give effect to the presumed purpose of the legislation? They lay down the law accordingly.

This judgment appeared to set the law free from the traditional canons of interpretation and with it, Graham J was suggesting, the requirement to draft legislation in the traditional British style. Mr Skemp was asked to comment on the judge's memorandum. He explained that his drafting of the Bill involved changes to bring clarity as well as changes due to differing policy, and he went on to explain as the Bill was drafted before Buchanan: ${ }^{67}$

... I had to consider what approach to adopt. If I had been sure that our courts would interpret the Bill as if it were an international convention, I might have copied the language of the two patent conventions even more closely than I have. But I could not be sure - indeed despite Denning's judgment in Buchanan, one still cannot be sure. But I have to be sure. My Bills must be judge-proof. Thus I was driven to draft the Bill like any other piece of domestic legislation so as to give effect to the policy in accordance with the hitherto accepted cannons of construction ...

This brings me to Graham J's letter. In the first place, it is wrong to assume that it is I alone who have put my interpretation of the convention into the Bill. What I did was to give the ambiguous passages the meaning which my instructing team (some of whom helped draft the convention) and I agreed was the most likely.

Second, this Bill is not an international convention ... If the department or Parliament chose to depart from the conventions, they are fully entitled in our country to do so. And legislation in this country is still for Parliament and ... not for the judge.

He then went on to suggest that Lord Denning's remarks in Buchanan were obiter and the House of Lords might have a different view from the Court of Appeal when it heard the Buchanan appeal. He concludes:

At the time I took my decision on how to draft the Bill it would have been irresponsible to bank on the courts taking the line now taken by Denning. And now the curtain is up, it is hardly practicable to change the Bill ... But at the end of the day I find the patent agents' views unfair, impractical and misconceived.

The judges, after receiving a letter from Sir Denis Dobson ${ }^{68}$ setting out similar views to Skemp's, ${ }^{69}$ accepted the difficulties faced, but asked that any changes to drafting

66. [1977] QB 208 at 213.

67. Letter from Skemp to Collon, 21 March 1977 (Patents Bill Papers) (emphases in original).

68. Sir Derek Dobson, QC, KCB, OBE (Permanent Secretary to the LCO, 1968-1977).

69. Letter from Dobson to Graham J, 25 March 1977 (Patents Bill Papers). 
which were still possible could be made. ${ }^{70}$ At the same time as Dobson was writing to the judges, Mr Ellis wrote to the Patent Office, ${ }^{71}$ and his concerns, which by then had been picked up by the judges and the profession more generally, were putting the Office under 'much pressure' to align domestic law with the Conventions. ${ }^{72}$ The Bill team, while acknowledging some of the points Mr Ellis made, believed these could not be fixed by simply adopting a copy-out approach ${ }^{73}$ - for the reasons outlined already.

\section{OTHER REASONS FOR DIFFERENCE}

These machinations drew out other reasons why the Patents Bill could not be a simple 'copy-out'. For example, some obligations existed in both the Community Patent Convention and the European Patent Convention ${ }^{74}$ and the drafting of both Conventions differed; in such a case the question arises, which should the draftsman 'copy out'? Further, the drafting of the Patents Bill was not intended to implement an international convention only, rather Part I created a new domestic law of patents (as the heading makes clear: 'New Domestic Law'). It was (and is) Part II of the Patents Act 1977 that gives effect to the various Conventions. ${ }^{75}$ Thus, if a 'copy-out' had been adopted for Part I then the provisions of that part when being construed in relation to a domestic patent would have required the traditional canons of construction to be used ${ }^{76}$ and the liberty granted to the courts by Lord Denning's judgment would not have helped. Indeed, when it came to copying out the Conventions, the Lord Chancellor explained the Government view during Second Reading: ${ }^{77}$

One point which was referred to by a number of noble Lords, including the noble Lords, Lord Lyell and Lord Alexander of Potterhill, was the desirability, where we are harmonising our own domestic law with the provisions of the Convention, that we should so far as possible use the same language. Of course, the difficulty we are in here is the difficulty of translation. I remember some time ago addressing the Council of Europe and I referred to the 'common lawyers of the United Kingdom'. This was translated as 'les juristes très ordinaires du Royaume Uni'! So we do confront these questions of translation, but we are certainly prepared to examine the delicate question that was raised in regard to Clause 1 of the Bill as to the alternative words that were used there. But in principle, obviously, if we are going to apply the same law we should try to do our best to use the same language.

70. Noted in Letter from Collon to Skemp, 15 April 1977 (Patents Bill Papers).

71. Letter dated 25 March 1977 (only the attached note, 'Some points of difference between Patents Bill, EPC \& EPC' is in the Patents Bill Papers - ie the substance of the concerns remains in the Patents Bill Papers).

72. Ronald Bowen (Assistant Comptroller, Patent Office) to Evans: Patents Bill, 6 April 1977 at [1] (Patents Bill Papers).

73. Bowen to Evans: Patents Bill, dated 6 April 1977 at [2] and [3] (Patents Bill Papers).

74. Eg CPC, art 25(c) (1989 Agreement) and EPC, art 64(2): see Pioneer Electronics $v$ Warner Music [1995] RPC 487 at 494-5, Aldous J (accepted on appeal [1997] RPC 757, 763).

75. In relation to Community Patents, these were not to be governed by the Act at all but by Convention itself and by regulations (never) made by the Secretary of State - see Patents Act 1977, ss 86 (now repealed along with ss 87 and 88: Patents Act 2004, Schedule 3).

76. Submission from Collon to Widdows and Dobson (No 465/1/16), 20 March 1977 at [2] (Patents Bills Papers); stated publicly by Ronald Bowen, 'The Changing Patent Scene' in Mary Vitoria (ed.), The Patents Act 1977: Queen Mary College Patent Conference Papers (Sweet and Maxwell 1978) 9 at 16.

77. HL Deb, 24 January 1977, vol. 379, cols 313-14. 
In Schütz v Werit ${ }^{78}$ after setting out this extract, Jacob LJ rightly points out that English was an authentic language of the treaties and so translations are not relevant. However, this does not totally answer the problem, as a submission to the Permanent Secretary at the Lord Chancellor's Office makes clear:

The English text of the Community Patent Convention is one of the seven authentic texts, and it is appalling. Quite apart from questions of style, there are places where it is wholly inaccurate. ${ }^{79}$

A badly translated 'authentic' text is not helpful: if six of the seven texts mean one thing and the English means another, falling back on its authenticity is not going to assist as other courts will adopt a different meaning.

Indeed, notwithstanding the Adjustment Resolution, there were departures from the Convention to give effect to policy differences ${ }^{80}$ (such as recommendations of the Banks Committee ${ }^{81}$ ) and so the Patents Act 1977 was not solely meant to implement the Conventions. One official even suggested (probably wrongly) that it was only a policy decision to try and have the domestic patent law and the Convention consistent; and it would have been permissible to retain an inconsistent domestic law. ${ }^{82}$

\section{SOME EXAMPLES OF DIFFERENCES}

To understand why Mr Skemp departed from the drafting of the Convention on occasions it is useful to look at some provisions of the Patents Act 1977 which have faced criticism and examine the Bill papers to try to ascertain why the drafting decisions were made. The three examples below relate to 'non-inventions', the priority interval and the drafting of the infringement provisions.

\subsection{Exclusion 'as such'}

Ironically, the actual drafting of the 1977 Act adopted by Mr Skemp follows the policy of the European Patent Office more closely than the text of the Convention itself. The following is an extract of Article 52 of the Convention (emphases added):

(2) The following in particular shall not be regarded as inventions within the meaning of paragraph 1:

(a) discoveries, scientific theories and mathematical methods;

(b) aesthetic creations;

(c) schemes, rules and methods for performing mental acts, playing games or doing business, and programs for computers;

(d) presentations of information.

78. [2011] EWCA Civ 303, [2011] FSR 19 at [39].

79. Submission from Collon to Widdows and Dobson (No 465/1/16), 20 March 1977 at [3] (Patents Bill Papers).

80. Letter from Skemp to Collon, 21 March 1977 (Patents Bill Papers); also see Letter from Dobson to Graham J, 25 March 1977 (Patents Bill Papers).

81. Banks Committee to Examine the Patent System and Patent Law (1970) (Cmnd 4407).

82. Letter from Dobson to Graham J, 25 March 1977 (Patents Bill Papers). It is not clear how this is compatible with the Adjustment Resolution. 
(3) Paragraph 2 shall exclude the patentability of the subject-matter or activities referred to therein only to the extent to which a European patent application or European patent relates to such subject-matter or activities as such.

In Shopalotto.com's Patent Application, ${ }^{83}$ Pumfrey J said that the drafting of section 1(2) and the reason for the differences from article 52 'must remain shrouded in mystery'. ${ }^{84}$ Fortunately, this is not the case as Mr Skemp explained his reasons. ${ }^{85} \mathrm{He}$ was concerned that Article 52(2) and (3) relate to three different things. He explained that Paragraph (2) qualifies the meaning of 'invention', whereas paragraph (3) qualifies the meaning of 'patentability' - a different concept - and also it relates this qualification to a patent (or application for a patent), which is a different thing again. Thus, as he put it: 'the Article shifts from one plane to another and from the second plane to yet a third. This is both illogical and unattractive' ${ }^{86}$ Put simply, the strict reading means that something which is not an invention (eg an aesthetic creation) is only excluded from patentability where it is claimed 'as such' (ie a non-invention is patentable when it is not claimed 'as such').

The modern approach at the European Patent Office is to say that something which has a technical character is 'an invention' and so is not excluded from patentability as it is not claimed as such. ${ }^{87}$ This is exactly how Mr Skemp drafted section 1(2) of the Patents Act 1977, but it is not how the EPC itself is expressed. ${ }^{88}$ Despite these differences, when the court first came to consider section 1(2) it used section 130(7) as a lens to read the two provisions as having the same meaning. ${ }^{89}$ Now of course the domestic approach is different from that of the Boards of Appeal despite the provisions stated as having the same intended effect (albeit the English courts say the outcome is the same). ${ }^{90}$

\subsection{Section 6 - priority interval}

It was section 6 of the Patents Act 1977 which was the brunt of Jacob J's criticism in Beloit Technologies. ${ }^{91}$ However, in that instance the criticism was quite unfair. The

83. [2005] EWHC 2416 (Pat), [2006] RPC 7 at [5].

84. Also see Symbian v Comptroller of Patents [2008] EWCA Civ 1066, [2009] RPC 1 at [6].

85. Letter from Skemp to Christopher Robson (Department of Trade, Solicitors): Patents Bill: Part I, 27 October 1976 (Patents Bill Papers).

86. Letter from Skemp to Robson: Patents Bill: Part I, 27 October 1976 (Patents Bill Papers). 87. See T 154/04 Estimating sales activity/DUNS LICENSING [2008] OJ EPO 46 confirmed G 3/08 Computer programs [2011] OJ EPO 10 at [r 10.13.20]; see generally Roughton, Johnson and Cook, The Modern Law of Patents (3rd edn, Lexisnexis 2014) at Chapter 3.

88. A further criticism of the domestic legislation comes from Pumfrey $\mathbf{J}$ who believed that EPC, rather, associates the excluded subject matter with industrial applicability (Halliburton Energy Services v Smith International [2005] EWHC 1623 (Pat), [2006] RPC 2 at [210], Pumfrey J). At the time, art 52(4) of the EPC excluded medical methods by way of deeming them not industrially applicable (under EPC 2000 it is simply an exclusion: art 53(c)).

89. Merrill Lynch Inc.'s Application [1988] RPC 1 at 12, Falconer J (the drafting differences were not mentioned on appeal [1989] RPC 561).

90. See Aerotel v Telco Holdings [2006] EWCA Civ 1372, [2007] RPC 7; Symbian v Comptroller-General of Patents [2008] EWCA Civ 1066, [2009] RPC 1; HTC European v Apple Inc. [2013] EWCA Civ 451.

91. See the extract set out at the beginning of this discussion. 
section originated from a proposal by $\mathrm{CIPA}^{92}$ to avoid self-collusion (claiming priority from an earlier application and so destroying the novelty of the application in suit), and was put forward as an opposition amendment. The Government resisted the amendment, but lost the division. ${ }^{93}$ When forced to adopt the policy, Mr Skemp was compelled to draft an amendment that fitted with the policy the government had unsuccessfully resisted. But he described the implementation of the policy by way of two alternative drafts as demonstrating 'the silliness of the whole exercise' and how 'the choice between those words is itself embarrassing'. ${ }^{94}$ Thus, the draftsman himself believed the drafting was inappropriate, yet Parliament made it clear that it wanted such a clause. It is Parliament itself - and not the draftsman - who should be blamed for this difference between the Convention and the Act.

\subsection{Section 60 - infringement}

The drafting of the infringement provisions was based on art $29^{95}$ of the Community Patent Convention. This includes impossible acts of infringement, as the following extract shows (emphasis added):

A Community patent shall confer on its proprietor the right to prevent all third parties not having his consent:

(a) from making, offering, putting on the market or using a product which is the subject matter of the patent, or importing or stocking the product for these purposes; ...

Importing (or indeed stocking) for the purposes of 'making' is clearly impossible and Mr Skemp thought the use of the words 'for these purposes' to be 'ridiculous', ${ }^{96}$ and so his draft, section 60(1)(a) of the Patents Act 1977, makes sense as it refers to 'disposal or otherwise'. The re-drafting did, however, appear to widen the scope of infringement by using the word disposal (rather than stocking) - albeit the courts accepted that the meaning intended was not the 'ordinary' meaning and so saved the Act from a 'ridiculous' interpretation the other way. ${ }^{97} \mathrm{Mr}$ Skemp also rewrote CPC, article 25(b) in such a way as to make it ambiguous as to whether knowledge was required for both types of process claim infringement or just one type, as is clear from the text of the CPC. This too remains unresolved. ${ }^{98}$

92. Report to Council: 'Patent Law Reform' (1977) 6 CIPA J 534 at 543-4 (to mirror s 52 of the Patents Act 1949).

93. See HL Deb, 17 May 1977, Vol 383, col 581 to 591 (Amendment 33); once the division was lost the government put forward an amendment that fitted with the drafting of the rest of the Bill: see HC Standing Committee D, 5 July 1977, col 170-71 and 210.

94. Letter from Skemp to Robson, 2 June 1977 (Patents Bill Papers).

95. Article 25 in Agreement relating to the Community patent (the 1989 Agreement) [1989] OJ L40/1.

96. Letter from Skemp to Collon, 21 March 1977 (Patents Bill Papers).

97. See Kalman v PCL Packaging [1982] FSR 406, 412, Falconer J; also Lord Lyell, HL Deb, 15 March 1977, Vol 380, col 1483.

98. Compare: Simon Thorley et al., Terrell on the Law of Patents (17th edn, Sweet and Maxwell 2011) at [14-45]; Roughton, Johnson and Cook, The Modern Law of Patents (3rd edn, Lexisnexis 2014), at [7.42] (knowledge not required for using a process); with Bently and Sherman, Intellectual Property Law (4th edn, Oxford 2014) at 619 (knowledge required for both offering to use and using a process). 
These are three well-known examples of different drafting being adopted in the Patents Act 1977 from that in the EPC or CPC. Others examples include: (i) the use of the phrase 'breach of confidence' instead of 'evident abuse' ${ }^{99}$ in relation to non-prejudicial disclosures in terms of novelty (indeed, this is one of the few places where the Irish Patents Act $1992^{100}$ follows the UK Act, rather than the EPC); (ii) the explanatory words for 'aesthetic creation' so that it reads 'a literary, dramatic, musical or artistic work or any other aesthetic creation whatsoever'; ${ }^{101}$ and (iii) the claimed invention being 'capable' rather than 'susceptible' to industrial application. ${ }^{102}$ There are many other minor differences, but these should give a flavour of the draftsman's concerns. Our discussion now turns to whether Mr Skemp was right about not bending to the Buchanan wind.

\section{SKEMP WAS RIGHT (AT LEAST FOR A WHILE)}

When James Buchanan v Babco ${ }^{103}$ reached the House of Lords, their Lordships all disagreed with the approach advocated by Lord Dennning. ${ }^{104}$ Notwithstanding Lord Denning's 'modern' approach still being slightly too radical it was clear that times were changing; in particular, Lord Wilberforce overruled the strict approach in Ellerman Lines. ${ }^{105}$ An earlier House of Lords decision, not mentioned in Buchanan (or in any of the Patents Bill correspondence), had already tamed the beast in any event. Lord Diplock, now in the House of Lords, opined in The Jade ${ }^{106}$ that:

If there be any difference between the language of the statutory provision and that of the corresponding provision of the Convention, the statutory language should be construed in the same sense as that of the Convention if the words of the statute are reasonably capable of bearing that meaning.

The modern approach to interpreting a domestic statute to be in conformity with the relevant convention came with the House of Lords decision in Fothergill v Monarch Airlines Ltd. ${ }^{107}$ It adopted what might be called a purposive approach to implementing statutes. The approach in Fothergill might even have saved Part I from a purely domestic interpretation (although for the reasons outlined above that is not certain), but instead the Patents Act 1977 included a statutory mechanism to achieve the

99. Compare PA 1977, s 2(4) and EPC, art 55(1)(a). Indeed, Dr Singer suggested a breach of confidence would not be covered by evident abuse at this time: John CH Ellis, 'Terminological Differences between the Patents Act 1977 and the European and Community Patent Conventions' in Mary Vitoria (ed.), The Patents Act 1977: Queen Mary College Patent Conference Papers (Sweet and Maxwell 1978) 21 at 27; the limited case law suggests he was wrong: T 173/83 Evident abuse/TELECOMMUNICATIONS [1987] OJ EPO 465.

100. Patents Act 1992, s 12(a).

101. Compare PA 1977, s 1(2)(b) and EPC, art 52(2)(b).

102. Compare PA 1977, s 3 and EPC, art 57.

103. [1978] A.C. 141.

104. [1978] A.C. 141, 153 (Lord Wilberforce), 156 (Viscount Dilhorne), 160 (Lord Salmon), 168 (Lord Edmund-Davies).

105. [1978] A.C. 141, 153 (Lord Wilberforce).

106. [1976] 1 WLR 430 at 436.

107. [1981] AC 251; also see Richard Gardiner, 'Treaty Interpretation in the English Courts since Fothergill v Monarch Airlines (1980)' (1995) 44 ICLQ 620. 
same end: section 130(7). That provision was described as a 'rather novel device'108 by Skemp himself and later as 'heretical' in Genetech's Patent ${ }^{109}$ and a 'curious' provision which is 'unique in our legislation' in Kakkar v Szelke. ${ }^{110}$ Section 130(7) reads:

Whereas by a resolution made on the signature of the Community Patent Convention the governments of the member states of the European Economic Community resolved to adjust their laws relating to patents so as (among other things) to bring those laws into conformity with the corresponding provisions of the European Patent Convention, the Community Patent Convention and the Patent Co-operation Treaty, it is hereby declared that the following provisions of this Act, that is to say, sections 1(1) to (4), 2 to 6, 14(3), (5) and (6), 37(5), 54, 60, $69,72(1)$ and (2), 74(4), 82, 83, 100 and 125 , are so framed as to have, as nearly as practicable, the same effects in the United Kingdom as the corresponding provisions of the European Patent Convention, the Community Patent Convention and the Patent Co-operation Treaty have in the territories to which those Conventions apply.

The use of the words 'as far as practicable' were to allow the use of English terminology rather than that under the respective Conventions when the latter had 'no meaning' in the United Kingdom, as well as to make geographical alterations to the Convention texts. ${ }^{111}$ The latter was necessary because, for example, the EPC referred to 'European' patent and applications and 'Contracting States'. ${ }^{112}$ Indeed, this is why the EPC being purely incorporated by reference would not have worked. ${ }^{113}$ As Mr Ellis pointed out, the incorporation by reference approach would only work for some of the provisions in any event, as domestic provisions would be needed for things like Crown use, compulsory licences, employer/employee relationships, registration of licences and assignments, revocation procedure and so forth. ${ }^{114}$

The application of section 130(7) to the EPC and the Patent Co-operation Treaty (PCT) has never been doubted, but in Coflexip SA v Stolt Offshore MS Ltd (No 2) ${ }^{115}$ there were mixed views as to whether it applied to the Community Patent Convention as that Convention never came into force. At first instance, Jacob J held that as section 130(7) was an interpretative provision it did not matter that the CPC was not in force, ${ }^{116}$ but the Court of Appeal thought it might matter because, in fact, there are

108. Letter from Skemp to Collon, 21 March 1977 (Patents Bill Papers); a similar term was used in a presentation by Ronald Bowen, 'The Changing Patent Scene' in Mary Vitoria (ed.), The Patents Act 1977: Queen Mary College Patent Conference Papers (Sweet and Maxwell 1978) 9 at 17.

109. [1989] RPC 147, 197, Purchas LJ.

110. [1988] FSR 97, 104, Falconer J.

111. Letter from Skemp to A Perry (FCO): Patents Bill, 17 January 1977 (Patents Bill Papers). 112. Letter from Skemp to Perry: Patents Bill, 17 January 1977 (Patents Bill Papers).

113. See lament of Jacob LJ in Grimme Landmaschinenfabrik v Derek Scott [2010] EWCA Civ 1110, [2011] FSR 7 at [84] (he suggests this was how the Brussels Regulation was implemented; as that Regulation was directly applicable it is presumed he means the Brussels Convention which was implemented under the Civil Jurisdiction and Judgments Act 1982); an attempt to draft such a provision was included in John CH Ellis, 'Terminological Differences between the Patents Act 1977 and the European and Community Patent Conventions', in Mary Vitoria (ed.), The Patents Act 1977: Queen Mary College Patent Conference Papers (Sweet and Maxwell 1978) 21 at 23.

114. John CH Ellis (n 113) 21 at 23.

115. [2004] EWCA Civ 213, [2004] FSR 34.

116. Coflexip SA v Stolt Offshore MS Ltd (No 2) [2003] EWHC 1892 (Pat), [2004] FSR 7 at [44], Jacob J. 
no 'territories to which [the CPC] applies'. Ultimately, however, the court did not have to decide the point, ${ }^{117}$ rather, subsequently, in Rhone-Poulec $v$ Yeda ${ }^{118}$ Jacob LJ followed his earlier view and said the CPC could be used for interpretation notwithstanding it never came into force. Further support for section 130(7) comes from the courts having to take judicial notice of the EPC and decisions of the Board of Appeals. ${ }^{119}$

\section{THE EARLY RECEPTION OF SECTION 130(7)}

It appears that when the courts first applied section 130(7) they thought it did little more than give effect to the rule that comes from The Jade $e^{120}$ and allow for references to the Conventions to be made where the domestic law is capable of bearing the same meaning ${ }^{121}$ - it did not (as later cases seem to have read it) allow for the domestic text to be ignored. Accordingly, for many years, section 130(7) was received with quiet understanding - well demonstrated in Kakkar v Szelke where Price LJ stated: ${ }^{122}$

I shall at a later stage revert to the provisions of the Convention and the Protocol but, for the present, state only that it does not appear to me that section 130(7) or any of such provisions can afford any great assistance. If the statute specifically declares that certain provisions are so framed as to have as nearly as practicable certain results, it recognises that there are or may be certain shortcomings in its efforts. If therefore a particular section appears not to have achieved the desired result, it must, prima facie, be because it was impracticable to do so. Furthermore, although on proper material, resort might, as it appears to me, be had to the provisions of the Treaty, the Protocol and the laws of other states in order to assist in the resolution of any ambiguity, I am unable to see how any such resort could be had in the present case. There may be differences in the effects of the Convention provisions in the various territories to which the Convention applies of which we know nothing. Unless the effects were known, it is difficult if not impossible to derive assistance from the provisions themselves.

As time passed, the courts' view of section 130(7) became more robust. In Gale's Application the Court put it bluntly that the intention of Parliament was that there should be uniformity' ${ }^{\prime 23}$ and so that was what the court did - it strived to keep the domestic law uniform with that under the EPC. Indeed, even where a provision was not listed in section 130(7), the interrelationship of the various sections of the 1977 Act meant that the courts were often (but not always ${ }^{124}$ ) willing to look at

117. Coflexip SA v Stolt Offshore MS Ltd (No 2) [2004] EWCA Civ 213, [2004] FSR 34 at [127 to 130], Neuberger LJ (and the other two members of the court also liked the submission at [164]).

118. [2006] EWCA Civ 1094, [2007] RPC 9 at [24 to 30].

119. PA 1977, s 91(1); see John Wyeth \& Brother [1985] RPC 545 at 565-6, Whitford and Falconer JJ; Mentor Corporation and Another v Hollister Incorporated [1993] RPC 7 at 10, Lloyd LJ.

120. [1976] 1 WLR 430.

121. Smith, Kline and French Laboratories v R D Harbottle (Mercantile) Ltd [1980] RPC 363 at 372-3, Oliver J (followed Asahi Kasel's Application [1990] FSR 546, 550, Dillon LJ); similarly see Agfa-Gevaert's Application [1982] RPC 441 at 454, Falconer J.

122. [1989] 1 FSR 225 at 232, CA.

123. [1991] RPC 305 at 322, Nicholas LJ.

124. Ament's Application [1994] RPC 647 at 656-7, Aldous J (restoration not mentioned in s 130(7) and so no need to follow EPO) (at the time the standard for restoration under the PA 1977 and EPC was the same - it is now different); Baxter International v Nederlands 
Board of Appeal jurisprudence, albeit justifying it using grounds other than section $130(7) .{ }^{125}$

When a provision was listed in section 130(7) then the Courts would readily turn to the text and the Board of Appeal jurisprudence relating to it. Furthermore, the CPC was used to assist with the interpretation of section 60 (and it was section 130(7) itself which was referred to when the unduly wide meaning of disposal was not adopted by the court ${ }^{126}$ ), and similarly where the question related to the scope of experimental use the CPC provision was referred to by way of section 130(7). ${ }^{127}$ Most references to section 130(7) have been a simple acknowledgement that its purpose was for the relevant provision of the Patents Act 1977 to have the same meaning as that in the Convention; and so over the years references have been made to section 130(7) on the law of priority, ${ }^{128}$ revocation, ${ }^{129}$ the Protocol on Recognition, ${ }^{130}$ the scope of protection, ${ }^{131}$ and infringing acts, ${ }^{132}$ as well as added matter. ${ }^{133}$ This has largely led to the same (or at least similar) rules being applied before the domestic courts as before the European Patent Office (EPO). As Jacob LJ pointed out in Markem $v$ Zipher, ${ }^{134}$ 'No one has ever identified any difference in meaning between a 1977 Act provision and the meaning of a corresponding provision of the EPC and we do not suppose anyone ever will'.

Produktielaboratorium [1998] RPC 250, 252-3, Jacob J (assignment provisions); also see Palmaz's European Patents [1999] RPC 47, 61-2, Pumfrey J; and Kimberly-Clark Worldwide Inc. v Procter \& Gamble [2000] RPC 422, Aldous LJ.

125. Flexible Directional Indicators [1994] RPC 207 at 212-13, Aldous J (link between s 72(1) (d) and 76(2) which are in identical language and the former is in s 130(7) so best to interpret the latter consistently as well); Kirin-Amgen's EP Application [2002] EWHC 471 (Pat), [2002] RPC 43 at [47] (using general rules for international treaty interpretation when not listed in s 130(7)); Daido Kogyo Patents [1984] RPC 97, 111, Falconer J (restoration looking at EPC); Abbott Laboratories v Medionol [2010] EWHC 2865 (Pat) at [65 to 70], Arnold J (abstract not part of the disclosure).

126. Kalman v PCL Packaging [1982] FSR 406, 412-13, Falconer J; also referred to in relation to that provision in Upjohn $v$ T Kerfoot \& Co. [1988] FSR 1 at 6-7, Whitford J.

127. Monsanto v Stauffer Co. [1985] RPC 515 at 537-8, Dillon LJ.

128. Abbott Laboratories v Evysio Medical Devices [2008] EWHC 80 (Pat), [2008] RPC 23 at [224], Kitchin J. The original policy was for s 5 not to be included in s 130(7) and there was originally a deliberately different policy. But this disappeared following the Ellis letter: Bowen to Evans: Patents Bill, 6 April 1977 at [7] (Patents Bill Papers); amendment made HL Deb, 28 April 1977, Vol 382, col 698.

129. Bonzel v Intervention (No 3) [1991] RPC 553 at 573-4, Aldous J; Henry Bros (Magherafelt) $v$ Ministry of Defence [1999] RPC 442 at 450-51.

130. PA 1977, s 82; Kakkar v Szelke [1988] FSR 97 at 104, Falconer J; [1989] 1 FSR 225.

131. PA 1977, s 125 and EPC, art 69; see Improver Corp v Remington [1989] 69, 74-5, Dillon LJ; also see Southco Inc. v Dzus Fastener Europe [1989] RPC 82, 83, Aldous J; Daily v Etablissements Fernand Berchet [1991] RPC 587 at 592, HHJ Ford; Hoechst Celanese v BP Chemicals [1999] FSR 319 at 323-4, Aldous LJ; American Home Products Corp. v Novartis Pharmaceuticals [2000] RPC 547, Laddie J.

132. PA 1977, s 60; Gerber Garmet Technology v Lectra Systems [1995] RPC 383 at 411-12, Jacob J; Menashe Business Mercantile v William Hill [2003] RPC 31 at [11 and 12], Aldous LJ. 133. Abbott Laboratories v Evysio Medical Devices [2008] EWHC 80 (Pat), [2008] RPC 23 at [229], Kitchin J.

134. [2005] EWCA Civ 267, [2005] RPC 31 at [94]. 


\section{PERMISSION TO LOOK ABROAD}

This, however, skips what was probably the formative moment - the House of Lords decision in Merrell Dow v Norton ${ }^{135}$ where Lord Hoffmann explained:

[section 130(7) means] It is ... the duty of the United Kingdom courts to construe section 2 so that, so far as possible, it has the same effect as Article 54. For this purpose, it must have regard to the decisions of the European Patent Office ('EPO') on the construction of the EPC. These decisions are not strictly binding upon courts in the United Kingdom but they are of great persuasive authority.

Thus, the highest court was acknowledging that decisions of the Boards of Appeal could (and indeed should) be of high (albeit not binding) authority in English courts. This primarily comes not from the more liberal rules on the interpretation of domestic statutes implementing international law but because of section 130(7). Since that decision, the highest court has repeatedly held that English courts (including the highest courts) should usually follow decisions of the Boards of Appeal of the EPO. ${ }^{136}$ Thus, section 130(7) enables English courts to give effect to (without being bound by) decisions of the European Patent Office and, increasingly, the Courts of other Contracting States to the EPC, as explained in Dr Reddy's Laboratories v Eli Lilly: ${ }^{137}$

Especially in relation to those concepts covered by the sections of the 1977 Act identified in section 130(7), it is plainly desirable that there is, so far as possible, a consistency of approach when it comes to matters of principle between the domestic courts of the signatory states to the EPC.

The most a court can do, absent section 130(7), is consider the reasoning of the foreign court and see whether it should apply by analogy in the English courts (ie the classic view of persuasive authority). ${ }^{138}$ But section 130(7) has allowed the courts to go further and depart from traditional rules of construction, as Jacob $\mathrm{J}$ explained in Menashe Business Mercantile Ltd v William Hill Organization Ltd: ${ }^{139}$

It also follows that one does not adopt the rather strict or linguistic approach to construction which might be called for in a freestanding United Kingdom Act. Rather one uses the approach used for the construction of international treaties. It is teleological, not strictly grammatical. What matters is the spirit and intendment - the purpose. And one can have regard to authentic versions of the Treaty in other languages. Also to any travaux préparatoires.

\section{YET SO MUCH CRITICISM}

Despite section 130(7) being central to the judiciary being set free to follow the text of the EPC and CPC, it has received substantial criticism - mainly from Jacob LJ. He

135. [1996] RPC 76.

136. Conor Medsystems v Angiotech [2008] UKHL 49, [2008] RPC 28 at [3]; Generics v Lundbeck [2009] UKHL 12, [2009] UKHL 12, [2009] RPC 13 at [71]; Human Genome Science v Eli Lilly [2011] UKSC 51, [2012] RPC 6 at [84]; Schultz v Werit [2013] UKSC 16, [2013] RPC 16 at [38].

137. [2009] EWCA Civ 1362, [2010] RPC 9 at [92]; the approach to take is explained by the Supreme Court in Schultz v Werit [2013] UKSC 16, [2013] RPC 16 at [40].

138. See Antiphon AB's Application [1984] RPC 1 at 3 (Hearing Officer, not dealt with on appeal). 139. [2002] EWHC 397, [2002] RPC 47 at [7]. 
described it as 'cack-handed' in Markhem v Zipher, ${ }^{140}$ as 'preposterous' in Grimme Landmaschinenfabrik $v$ Derek Scott, ${ }^{141}$ and in Schütz $v$ Werit ${ }^{142}$ he described himself as 'baffled, nay flabbergasted, by this convoluted and roundabout way' of implementing the Convention. His view had earlier led him to suggest in Bristol Myers Squibb v Baker Norton ${ }^{143}$ that section 130(7) allows the Patents Act 1977 to simply be ignored:

... section 130(7) is saying that the specified provisions of our Act are to have the same meaning as the corresponding provisions of the Conventions. The best way of achieving this is to work directly from those provisions and not to bother with the provisions of our Act. The provisions of the Convention are not merely an aid to interpretation - they are what our Act says its own provisions are intended to mean.

As a matter of principle, it is suggested, this goes too far. Indeed, despite the increasingly liberal use of international materials by the English Courts at all levels, it is suggested that section 130(7) remains a necessary provision and the correct point of reference is the text of the 1977 Act itself, as the speech of Lord Hoffmann in $R v$ Lyons makes clear: ${ }^{144}$

... it is firmly established that international treaties do not form part of English law and that English courts have no jurisdiction to interpret or apply them: JH Rayner (Mincing Lane) Ltd v Department of Trade and Industry $\left[{ }^{145}\right]$... . Parliament may pass a law which mirrors the terms of the treaty and in that sense incorporates the treaty into English law. But even then, the metaphor of incorporation may be misleading. It is not the treaty but the statute which forms part of English law. And English courts will not (unless the statute expressly so provides) be bound to give effect to interpretations of the treaty by an international court, even though the United Kingdom is bound by international law to do so. Of course there is a strong presumption in favour of interpreting English law (whether common law or statute) in a way which does not place the United Kingdom in breach of an international obligation .... [But t] he sovereign legislator in the United Kingdom is Parliament. If Parliament has plainly laid down the law, it is the duty of the courts to apply it, whether that would involve the Crown in breach of an international treaty or not.

Simply to disregard the Patents Act 1977 undermines the constitutional principle of Parliamentary sovereignty. As Daniel Greenberg has said in relation to European Union legislation, ${ }^{146}$

it seems questionable for judges to announce that they are proposing to ignore legislation enacted by Parliament .... and to take their text directly from the European Union. If not actually a contravention of Parliamentary Sovereignty, this attitude seems at least to be an affront to it.

While Greenberg presents a reconciliation of Parliamentary Sovereignty for this approach in relation to European Union law (namely Parliament intended in different

140. [2005] EWCA Civ 267, [2005] RPC 31 at [94].

141. [2010] EWCA Civ 1110, [2011] FSR 7 at [82].

142. [2011] EWCA Civ 303, [2011] FSR 19 at [39].

143. [1999] RPC 253 at [3], Jacob J; also see Schlumberger Holdings $v$ Electromagnetic Geoservices [2010] EWCA Civ 819, [2010] RPC 33 at [30].

144. [2002] UKHL 44, [2003] 1 AC 973, [27 and 28].

145. [1990] 2 AC 418.

146. Daniel Greenberg, 'The Copy-Out Debate in the Implementation of European Union Law in the United Kingdom' (2012) 6 Legisprudence 243 at 247. 
legislation to give effect to European law ${ }^{147}$ ) this cannot apply to a non-EU treaty. As Lord Hoffmann makes clear in $R v$ Lyons, reference to a treaty text, such as the EPC or $\mathrm{CPC}$, is only permissible because of a provision like section 130(7). So ignoring the Act itself remains constitutionally dubious, but it would be churlish to suggest that Jacob LJ went this far; rather, it is probable he was using a judicial shorthand for reaching an end result. Nevertheless, this shorthand is only allowed because of a provision he himself called 'preposterous' and 'cack-handed'.

\section{SO WAS IT ALL FAIR?}

When one looks at the drafting of the Patents Act 1977 today, in 2015, it is easy to criticize Mr Skemp by suggesting that he unnecessarily 'domesticated' the European Patent Convention and in so doing caused little but confusion. ${ }^{148}$ Yet this is exercising the greatest sin for any patent lawyer - looking at a document with hindsight. When Mr Skemp was drafting the Patents Bill nearly 40 years ago, he was already stretching the boundaries of 'acceptable practice' for Parliamentary Counsel. By using his 'novel' provision he ensured that the English courts were free to follow the European Patent Office to the extent they chose. As time has gone by, the English judiciary has had increasing respect for the Boards of Appeal and other jurisdictions, but they still sometimes go it alone; ${ }^{149}$ and Mr Skemp left both approaches open to the courts. Mr Skemp should be praised for his drafting, which was radical at the time (if not now), rather than damned for not copying out nearly 20 years before that was seriously considered a drafting option. The Patents Act 1977 works because of the freedom his 'preposterous provision' gave the judges - a freedom they use but strangely never accepted generously.

147. European Communities Act 1972, s 2(1).

148. See Grimme Landmaschinenfabrik v Derek Scott [2010] EWCA Civ 1110, [2011] FSR 7 at $[82]$.

149. Such as the Pozzoli/Windsurfing approach - see Pozzoli SPA v BDMO SA [2007] EWCA Civ 588, [2007] FSR 37 at [23] - to inventive step (rather than the problem and solution approach: Guidelines for Examination November 2014, G-VII, [5]; see in particular, T 31/84 Test Device/MILES [1986] OJ EPO 369): Actavis UK Limited v Novartis AG [2010] EWCA Civ 82, [2010] FSR 18 [26 to 34]; and the approach to excluded subject matter: see, most recently, HTC Europe v Apple [2013] EWCA Civ 451, [2013] RPC 30. 